\title{
Will promoting more typical SME start-ups increase job creation in South Africa?
}

\author{
Neneh Brownhilder Ngek* and A van Aardt Smit \\ Department of Business Management, University of the Free State Bloemfontein, South Africa, 9301.
}

Accepted 31 July, 2013

\begin{abstract}
Unemployment is one of the pressing issues that attract more attention in South Africa at the moment, with over $25 \%$ of the population jobless and the number increases to $40 \%$ when including the people who have totally given up the search for work. The South African government has continuously highlighted that the SME sector will be the key to increasing job creation in the country. However, there is evidence that the sector is characterized by high failure rates and low success, growth and survival rates. It is therefore vital to develop a new and fresh perspective in addressing the challenges facing the sector and establish policies to foster job creation in the SME sector. Evidence from around the world show that the SME sector is always characterized by a small subset of high growth, high quality firms that account for the bulk of job creation in the sector. This paper provides a review on the literature of some key characteristics of the small subset of SMEs with high job creation potential, and further appraises the potential of fostering these actors in the South African SME sector. The paper culminates with some policy measures for enhancing high growth SMEs in South Africa as a means to address the job creation saga.
\end{abstract}

Key words: Unemployment, job creation, small and medium enterprises (SMEs).

\section{INTRODUCTION}

One of the most important characteristics of a flourishing and growing economy is a booming small and medium enterprises (SMEs) sector. Data from both the developed and developing countries have established that the SME sector is a dynamic force for economic growth, innovation and job creation (Chodokufa, 2009; Andzelic et al., 2011). The National Small Business Act of South Africa of 1996, as amended in 2003 , defines an SME as "a separate and distinct entity including cooperative enterprises and nongovernmental organizations managed by one owner or more, including its branches or subsidiaries if any is predominantly carried out in any sector or sub-sector of the economy mentioned in the schedule of size standards and can be classified as a SME by satisfying the criteria mentioned in the schedule of size standards" (Government Gazette of the Republic of South Africa, 2003). The quantitative definition of SMEs in South Africa is stated in Table 1.

In South Africa, a study by the FinScope Small Business Survey (2010) established that there were approximately 5,579,767 small business owners in South Africa owning 5,979,510 small businesses. A healthy SME sector contributes to the economy through employment creation, generating higher production volumes, introducing innovation and entrepreneurship skills (Mahembe, 2011). Clover and Darroch (2005) pointed out that in South Africa, $80 \%$ of businesses are SMEs and encompass $56 \%$ of private sector employment and $40 \%$ of the gross domestic product (Biljon, 2012). Kongolo (2010) highlight that SMEs in South Africa represent about $91 \%$ of the formal businesses, provide almost $60 \%$ of employment and contribute about $51 \%$ to $57 \%$ of GDP. 
Table 1. Schedule of size standards for the definition of SMEs in South Africa.

\begin{tabular}{lcll}
\hline Types of firms & Employee & Turnover & Balance sheet \\
\hline Small & $1-49$ & Maximum R13 million & Maximum R5 million \\
Medium & $51-200$ & Maximum R51 million & Maximum R19 million \\
\hline
\end{tabular}

Source: Government Gazette of the Republic of South Africa (2003); Fatoki and Garwe (2010).

\section{Number of Employees (Excluding business owner)}

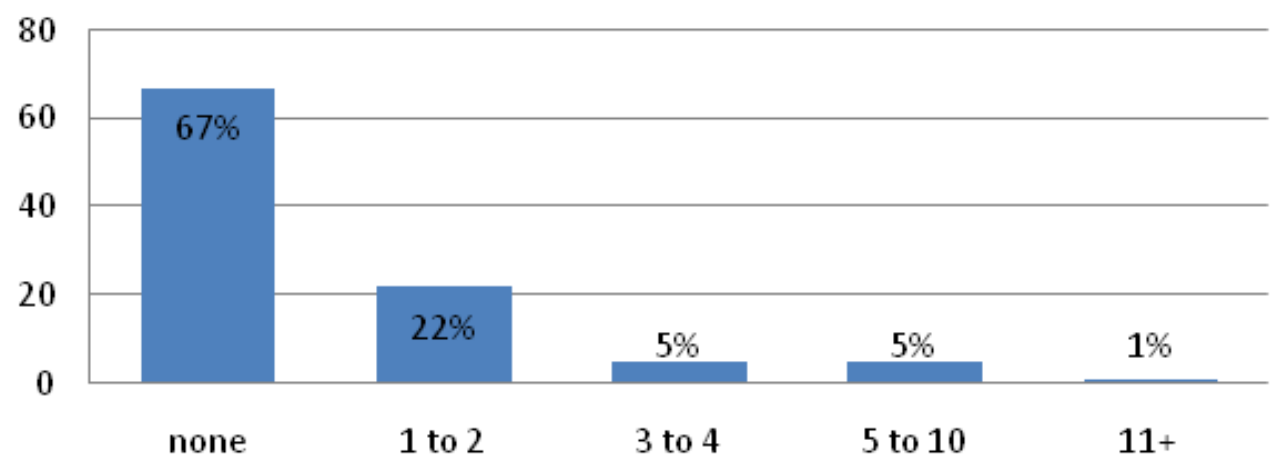

Percentage

Figure 1. Size of Small businesses in South Africa

Source: Finscope Small Business Survey 2010

Furthermore, a study by World Wide Worx, 2012 established that SMEs in South Africa provide around 7.8 million jobs (CIB, 2012). While, it can be concluded that a vibrant SME sector is one of the principal driving forces in the development of a country's economy, South Africa needs a total re-assessment of their SME development strategies in order to enjoy these benefits (Business environment specialist, 2009). For example, if 5,979,510 (5.9 million) small businesses create 7.8 million jobs, it clearly indicates that on average each small business creates less than 2 jobs. This is by no way an ideal situation if the South African government is to achieve its goal of using the SME sector as the job creation engine for reducing unemployment. Figure 1 shows some insight on the job creation potential of SMEs in South Africa indicating that $94 \%$ of South African small businesses have less than five employees with up to $67 \%$ having no employees

Despite the noted contribution of established SMEs and the expected contribution of new SMEs, the SME sector in South Africa is characterized by high failure rates, as the creation rate of new SMEs in South Africa is one of the lowest in the world (Fatoki, 2012; Fatoki and Odeyemi, 2010). In South Africa, the number of SME failures in the first five years varies between $50 \%$ and
95\% (Willemse, 2010) and about 75\% of new SMEs do not become established businesses, which has been identified as one of the highest in the world. Also, unemployment is the most pressing challenge in South Africa which stands at $25.5 \%$ (Statistics South Africa, 2012). Fatoki and Garwe (2010) note that most new SMEs in South Africa do not move from the first stage (existence) to other stages such as survival, success, take off and resource maturity. The 2009 Global Entrepreneurship Report (GEM) points to an alarming low level of entrepreneurship in South Africa. South Africa's Total Early-Stage Entrepreneurial Activity (TEA), which is the primary measure of new firm creation, is at 5.9 substantially less than all efficiency (11.2) and factordriven (17.9) economies surveyed by GEM in 2009. As such, it is believed that many of these SMEs do not survive in their first years of operation and thus, do not provide their benefits to society. With one of the highest unemployment rates and the biggest disparities in incomes and living standards in the world, creating jobs is central to economic growth and political stability in South Africa. SMEs are expected to be an important vehicle to address the challenges of job creation, sustainable economic growth, equitable distribution of income and the overall stimulation of economic development in South 
Africa (Maas and Herrington, 2008). Hence, considering that around 12.8 million people are employed in South Africa, while up to 16 million people depend on government grants to earn a living, it becomes imperative for the health of the South African economy that these SMEs succeed.

The South African government has acknowledged the need to promote the SME sector as a means to foster economic growth and job creation by establishing a host of government initiatives to address the financing needs of SMEs, facilitate SME creation, foster and increase entrepreneurship activity in the country and also help in poverty alleviation; create wealth for previously disadvantaged people and create lucrative opportunities for indigenous entrepreneurs (Morris and Zahra, 2000). However, despite such increased efforts, entrepreneurship is not as "activated" as it should be and bringing attention to the country's 'base' of high-impact entrepreneurs is a great starting point to address this problem. This review is motivated by the believe that the various stake holders in the South African SME sector need to rethink the approach to foster SME growth as a means to generate more jobs. According Boysen 2010 (cited in Morgan, 2012) "To fully realise the potential of SMEs in South Africa, the sector needs to be approached with a fresh perspective attuned to the challenges it faces". From the Finscope Small Business Survey (2010) it was established that only $6 \%$ of SMEs had more than 5 workers but contributed $26 \%$ more jobs than the other $94 \%$ of small business. This review aims at documenting the perspective that it is time for the South African government to lay more emphasis on the 6\% SMEs that significantly contribute to employment growth and find strategies to transform the typical start-ups to high growth SMEs with significant job creation potential. The subsequent sections review some key characteristics of SMEs worldwide with high job creation abilities and further documents the effect of these characteristics in the South African SME sector. Lastly the review culminates with some policy considerations for fostering high growth SMEs in South Africa as a means to increase the job creation potential of the SME sector.

\section{SME'S AND JOB CREATION}

While SMEs remain a key player in the creation of jobs in most countries, not all SMEs have the ability to generate a significant number of jobs (Henrekson and Johansson, 2009). Prior empirical evidence has highlighted the fact that it is a small number of high growth, high quality SMEs that account for a huge percentage of jobs created by the SME sector. For example Birch et al. (1997) established that in the U.S, over $70 \%$ of jobs created in the SME sector between 1992 and 1996 were generated by only $3 \%$ of fast growing firms. Autio (2005) in the GEM report on "high - expectation entrepreneurship" also elucidated that $80 \%$ of total job creation was generated by high ambitious entrepreneurs who represented less than $10 \%$ of nascent and new entrepreneurs. In the UK, it has been established that over $50 \%$ of jobs created by all new firms ten years later is generated by only $4 \%$ of new start-up survivors. This statistics clearly propounds that job creation is not simply a numbers game depending on the number for new SMEs in an economy but rather a significant effect on job creation can be achieved by increasing the number of high growth, high quality SMEs. Henrekson and Johansson (2009), highlight that these high growth SMEs make up for the deficiency in job and wealth creation by the typical new SMEs. Since it is evident that only a limited number of so-called high growth SMEs make up the bulk contribution to job creation (Autio et al, 2000; Fritsch and Weyh, 2006; Schreyer, 2000; Storey and Greene, 2010), understanding and identifying these SMEs in an economy has become a key policy measure in most countries. Robert $\mathrm{E}$. Litan, the vice president of research and policy at the Kauffman Foundation proposed that "since fast-growing young firms account for a disproportionate share of net job creation, policymakers who are worriedly poring over unemployment projections might instead seek to foster the creation of more high-growth firms. "High growth SMEs generally exhibits some key characteristics. Some of these features which have been widely acknowledge include: innovation, networking, market orientation, teamwork, human capital, organizational structure, entrepreneurial growth ambitions (OECD, 2002; Europe INNOVA, 2011; Papadaki and Chami, 2002; Wells and Hungerford, 2011).

\section{CHARACTERISTICS OF HIGH GROWTH FIRMS}

Lots of studies (OECD, 2002; BERR, 2008; López-García and Puente, 2009; Vivarelli 2004; Stam and Schutjens, 2005) have identified the characteristics of high growth firms (HGFs): high level of innovation; human capital; growth ambition, market orientation, teamwork and networking, export-orientation; internationalisation; spillover effects, amongst others. This study will only focus on some of them.

\section{Innovation}

O'Sullivan and Dooley (2008) define innovation as "the process of making changes, large and small radical and incremental, to products, processes, and services that results in the introduction of something new for the organization that adds value to customers and contributes to the knowledge store of the organization". According to Lee and Hsieh, (2010), Drucker, 1985 defines innovation as resources new ability to create wealth, which can be trained and learned. Mitusch and 
Schimke (2011) identified innovation activities to be amongst the key drivers of the establishment of a healthy stock of high growth firms, which they termed gazelles. Empirical studies by the OECD (2002) pointed out that innovation is a driving force in high-growth firms and that most high-growth businesses respond to their customers' needs in novel and precise ways, maintain especially close relations with their clients and innovate to respond to their specific requirements and are more heavily committed to research and development. This study further established that a business growth is closely bound up with its ability to innovate and that the durability of growth is related to a company's skill at creating an upward spiral of innovation. Continual innovation encourages steady or regular product, production or organisational inventiveness. Findings from a study by (Vincent et al., 2004) pointed out that it is possible for firms to overcome the negative impact of competition on performance through creative innovation and invention. Innovation is the characteristic tool of entrepreneurs as it is a means of exploiting change to accomplish different businesses or services (Mirela, 2008), and also an important factor in a firm's survival, development and business success (Utterback, 1996). Krotowski (2012) asserts that about $1 / 3$ of economic growth is influenced by technological change, which thus explains why innovation and technological advancements are vital to the survival of every economy. Branscomb and Auerswald (2002) propound that incremental technological advancements alone is not suitable to ensure sustained growth and economic security; but that sustained economic growth will only occur when radical technological innovations and inventions are present (continuous introduction of truly new goods and service that will disrupt the markets and in return create new industries).

\section{Human capital}

OECD (2001) defines human capital as the knowledge, skills, competencies, and attributes embodied in individuals that facilitate the creation of personal, social and economic well-being". Fatoki (2011) states that the concept of human capital implies an investment in people through education and training. Human capital can be divided into general and specific human capital (Ganotakis, 2010). General human capital refers to the acquisition of an inclusive formal education and training that is relatively transferable across firms and industries (Carrera et al., 2003). Specific human capital refers to skills pertaining to a specific job (or position) that have no effect on the productivity of employees working in other firms (not transferable to other occupations). The BERR (2008) found that high growth firms in the United Kingdom and United States had higher levels of human capital and skills than lower growth firms. Furthermore, the BERR (2008) study also established that high growth firms usually tend to have founding entrepreneurs and management teams with higher educational attainment levels and skills levels than their lower growth counterparts. Bruderl and Preisendorfer (2000) explicitly emphasized that firms owned by the entrepreneurs with more educational background were more likely to experience fast growth. Chandler and Hanks (1994), established that high human capital employees facilitate firm growth by enabling management and owners to implement their growth goals. Likewise, López-García and Puente (2009) point out that high-growth firm spend more time and money on staff training and on hiring more qualified workers than the low growth firms. Additionally, another study by EIM (2006) identified human capital to be the key success factor for European most dynamic entrepreneurs in the 80 s.

\section{Growth ambition}

Friar and Meyer (2003) assert that high-growth firms contribute more to the economic growth than small firms and start-ups in general. Empirical research by Schreyer (2000) accentuates that it is not merely the creation of new firms that is the key to job creation but rather the relatively small number of fast growing new firms that account for the lion's share of net new job creation. Wiklund and Shepherd (2003) found the growth intentions of entrepreneurs to be positively related to actual firm growth. In identifying the possible determinants of growth ambition, Verheul and van Mil (2008) identified the individual-level determinants such as: sociodemographic factors (gender, age, and education), personality characteristics (opportunity, perception, risk attitude, entrepreneurial self-efficacy) and start-up motivation to be important in the pursuit of firm's growth. Other studies by (Vivarelli 2004; Stam and Schutjens, 2005) identified factors such as opportunity based entrepreneurship, the availability of a large information set, and a spatially broad market orientation in the startup phase to be factors that distinguishes entrepreneurs of future high growth ambitious firms from entrepreneurs of low growth ambitious firms. Wiklund and Shepherd (2003) further elucidated that the effect of growth motivation on realized growth is moderated by the level of education and experience of the entrepreneur, the dynamism of the environment in which the firm operates: education, experience and environmental dynamism magnify the effect an entrepreneur's growth motivation has on the realization of firm growth. Fischer and Reuber (2003) established that the networking among peers and mentoring by experienced entrepreneurs/managers is an effective and efficient mechanism to improve the growth of new firms.

\section{Market orientation}

Ferrell et al. (2010) define market orientation as "an 
organizational culture, which provides norms for behaviours that focus on assessing and acting on customers' needs and anticipating and responding to competitors' actions." Prior studies (Dobni and Luffman, 2003; Hult and Ketchen, 2001; Morgan et al., 2009) postulate that market orientation is a great source of competitive advantage for businesses. Kotler and Kruger (1995) propound that market orientation is a prerequisite for business success because it results in sustainable competitive advantage. Competitiveness is an important construct of economic development and affects an SME's ability to create jobs. Mason (2011) notes that highgrowth SMEs always have robust market orientation and customer engagement philosophies. Market orientation has been widely established to have a positive and significant effect of firm performance (Morgan et al., 2009; Kirca et al., 2005). This possibly explains the superior performance of high growth SMEs.

\section{A REVIEW OF SOME KEY HIGH GROWTH CHARACTERISTICS IN THE SOUTH AFRICA SME SECTOR}

The lack of innovation has been identified as one of the impediments to the growth and survival of SMEs in South Africa. A study Krause et al. (2012) found that many SMEs in South Africa were still in the early stages of open innovation rollout. Krause (2011) identified the lack of open innovation in many respects as an untapped opportunity for South African business and that innovation is especially relevant for SMEs in South Africa, since it has been internationally quoted as one of the key drivers in business success. Additionally, another study by Nenzhelele, (2009) on the factors influencing the productivity of SMEs in South Africa established that up to $53 \%$ of SMEs do not reward their employees for excellent innovations and thus accounts for one of the reasons amongst others as to why the level of innovative ideas in SMEs in slow. Neneh (2011) found that only 50\% of SMEs practice innovation and that innovation and business acumen are the two capabilities that are seen to affect business practices. Likewise, Neneh and Smit (2012) in their study established that only $36.75 \%$ are innovative in South Africa. Thus, given the low level of innovation identified in most studies in South Africa, it becomes imperative to enhance this low level of innovationas it is an important factor in a firm's survival, firm's development and business success (Utterback 1996) and also a key driver for the establishment of a healthy stock of high growth firms (Mitusch and Schimke, 2011).

The SME sector in South Africa suffers a crisis of low human capital. Toomey (1998) elucidated that the unemployed in South Africa are mostly unskilled or semiskilled. This is a critical concern especially for SMEs as the likelihood of creating employment might not have any positive marginal effect on productivity as skill levels are low. This suggestion is in line with the growth theory that propounds that firm growth rate is associated with the growth rate of out-put per person which is a consequence of the persons human capital (Solow, 1997). Thus with a high number of unskilled or semi-skilled unemployed people in south Africa, it will be more feasible to first increase their education and training before adopting them to the formal economy through employment in the SME sector. A study by Herrington et al. (2009) established that lack of human capital (education and training) is the highest cause of new SME failures in South Africa. Labuschagne (2010) is of the view that South Africa's under-achieving human capital is the main reason for its low level of competitiveness. In the 2011 competitiveness index, South Africa dropped from 44th position to 52nd position out of 59 countries in the 2011 IMD World Competitiveness Yearbook. In an OECD (2008) review of national policies in South Africa, it was identified that the enrolment and graduation patterns in higher education were very low especially in the fields of mathematics, science and technology. This OECD analysis elucidated that that the higher education system in South Africa was far from accomplishing its function "in terms of producing the high quality human capital needed to propel and sustain the social and economic development of South Africa."

Education has been established as one of the five key priority areas by the South African government (Department of Government communication and Information System, 2012). However, over half of the job seeking population still lacks some basic education as highlighted in the second quarter labour force survey by statistics South Africa in July 2012. The report by statistics South Africa (2012) elucidates that of the total 4.5 million people looking for work in the second quarter of $2012,58.6 \%$ of the job seekers did not have metric. This clearly indicates the lack of human capital in South Africa and poses a serious problem for SMEs seeking skilled working in certain domains. The Grant Thornton survey in the second quarter of 2012 identified lack of skilled workforce as one of the biggest obstacle of economic growth in South Africa (SAinfo, 2012). Fatoki (2011) also notes that lack of skills; experience and knowledge are some of the key factors limited entrepreneurship in South Africa. How then do we expect SMEs to achieve their role of fostering economic growth and development, while the necessary skills to drive business success are not available?

A couple of studies in the SME sector in South Africa have identified the positive impact human capital has of the growth and performance of SMEs (Fatoki, 2011; Rogerson, 2008). However, Fatoki (2011) highlights that even the SME owners in South Africa always lack the skills, experience and training associated to the businesses they create. Kleynhans (2006) also notes that the level of education in South Africa needs to be generally 
increased as low levels of literacy amongst entrepreneurs and unskilled workers highly hampers trainability. Human capital can therefore be used to increase the job creation ability of South African SMEs in two ways. Firstly, increasing the human capital of the SME owners will increase their ability to identify and act on opportunities thus shifting the curve from high necessity to high opportunity entrepreneurship in South Africa. Secondly, increase the human capital of the job seekers will make them employment ready and boost their ability to increase the per person output of SMEs as well as address the critical skill shortages in the South African economy thereby increasing the likelihood of absorbing the unemployed into the economy.

With regards to the growth ambition of SMEs in South Africa, Fatoki (2011) points out that the South African economy is characterised by a low growth rate, a high inflation and a high rate of unemployment. Fatoki and Garwe (2010) propounds that in spite of the great efforts by the South African government, most new SMEs have achieved limited growth. These researchers further assert that the real issue in new firm growth is that most new SMEs in South Africa do not move from the first stage (existence) to other stages such as survival, success, take off and resource maturity and as such do not provide their benefits to the society. The Accelerated and Shared Growth Initiative South Africa (2009) draw attention to the fact that on average a growth rate of 5\% between 2004 and 2014 is needed to achieve the social objective of the government and expects SMEs to contribute significantly to the expected growth rate. Nevertheless, Fatoki and Garwe (2010) elucidate that most SMEs in South Africa do not always contribute towards the promotion of economic growth as most small firms do not grow at all since they mostly exist as necessity entrepreneurs than opportunities entrepreneurs. Neneh (2011) established that SMEs in South Africa are necessity entrepreneurs. Vivarelli (2004) established that firms created by necessity entrepreneurs had an inferior performance to those of opportunity entrepreneurs. The high rate of unemployment of $25.5 \%$ (Statistics, South Africa, 2012), as the case in South Africa forces people into necessity entrepreneurship because they believe no other options for employment are available for them. As such, measures should be put in place to help the necessity entrepreneurs create sustainable businesses as a means to help alleviate poverty and reduce unemployment. A study by FinMark Trust (2006) reckons that one of the best ways to address this high rate of unemployment is to leverage the employment creation potential of small businesses.

\section{CONCLUSION AND RECOMMENDATIONS}

While many studies (OECD, 2002; BERR, 2008; LópezGarcía and Puente, 2009; Vivarelli, 2004; Stam and
Schutjens 2005) have established that high-growth firms contribute more to economic development than typical start-ups in general, South Africa still experiences problems of low levels of entrepreneurial activity, high SME failure rates coupled with high unemployment rates. A study by the business environment specialist (2011) pointed out that at least a quarter of the South African population is unemployed and the number rises to nearly $40 \%$ if those who have given up looking for work are included. This situation leaves an alarming proportion of the South African population frustrated and alienated which in turn threatens the economic success of the country as a whole. Given the failure of both the formal and public sector to absorb the increasing number of job seekers in South Africa, much efforts has focused on entrepreneurship and new firm creation and its potential for contributing to economic growth and job creation (Herrington et al., 2009). Nevertheless, current trends indicate that creating typical start-ups and giving out subsidies to SMEs in South Africa is not the way to enhance job creation which can contribute to economic development. South Africa needs to identify the SMEs with high growth potential and provide the necessary support to enhance their growth. This will entail providing an enabling environment for innovation and developing the necessary human capital to help SMEs address the high skill shortage in the sector. In order to enhance the creation of high growth SMEs that can create sustainable and so-called decent jobs and contribute to economic development, policy makers and the South African government need to:

1. Stop subsidizing the creation of typical start-up and focus on the subset of businesses with growth potential. This is because getting economic growth and jobs creation from entrepreneurs is not a numbers game but about encouraging high quality, high growth companies to be founded. Fritsch and Mueller (2004), discourages policy efforts aiming at increasing SMEs creation through giving out loans and subsidies. Based on the 'survival of the fittest' scenario regarding the market selection process, these researchers believe that loans and subsidies will instead promote the businesses with relatively low productivity to remain in the market, whereas those with high productivity will either have to reduce their output or exit. Fritsch (2011) stresses that policy efforts aiming at increasing merely the number of new SMEs will yield only a slightly positive or even a negative marginal economic effect on growth, but that more focus should be placed on increasing the quality of new SMEs created. Therefore more effort should be placed on increasing the number of high quality new SMEs rather than increasing merely the number of new SMEs, which will yield only a slightly positive or even a negative marginal economic effect on growth. Thus, in order to identify those high growth SMEs with the potential to contribute to economic development, government and policy makers should adopt a 
pro-activeness approach whereby instead of waiting for SMEs to approach the supporting agency, agencies can actively scan the environment for potential high-growth firms in order to develop customized support for them. However, care should be taken when using this approach as it may induce abusive practices as it grants significant power to the support agency. Likewise, the support agency on their needs to nurture their professionalism, their competence, and a certain degree of exclusivity in order to be able to provide real value to the high growth SMEs, coupled with credibility. Credibility is vital as highpotential firms may tend to reject public support as being inefficient and not sophisticated enough.

2. SMEs policies should be designed in a way that only entrepreneurs with growth ambitions who react in the intended way are rewarded. Vivarelli (2004) elucidates that if self-employed entrepreneurs and new firms with relatively low ambitions benefit from subsidies, the resultant effects (substitution and deadweight) might cause a major bias in the market selection process. A deadweight effect refers to the situation wherein the less efficient or unambitious entrepreneurs/ new firms are given subsidies, and as a result remain in the market as long as they can use the subsidy; while a substitution effect occurs when less efficient entrepreneurs/ new firms are given an artificial seedbed, while market competition would have induced them to leave the market. Stam et al. (2006) add that more specific measures should focus on the growth and fast growth programmes which entail the networking between the coaching of, and advice to entrepreneurs of high growth firms. They further stated that an increase in the visibility of entrepreneurs of high growth businesses may help reduce the negative expectations regarding the consequences of growth and thus act as successful role models for young people early in their occupational career.

3. Given that South Africa suffers from a low level of skills and competences and seeing that business angels bring specific skills into a business, are prepared to be involved in the development of the business and also take higher risks while venture capitalists maintain a strong oversight over the companies they invest in, with an opportunity for growth, Policy should focus on encouraging the creation of more business angels and venture capital firms, since they have a potential to create sustainable businesses that can create more jobs, as oppose to individual SMEs. Likewise, both general and specific human capital should also be developed in all SMEs and individuals currently seeking employment. Training appropriately skilled employees is a further vital dimension for business development based on value-add. With over $58.6 \%$ of the unemployed lacking basic education, there is need for the government to device strategies to encourage more people to attain basic educational skills. For instance, instead of giving subsidies to entrepreneurs to start businesses that will not find suitable skills to employ so that the business can increase production and grow, such funds should rather be invested in building the skills of the unemployed and uneducated youths.

4. Access to finance, is not the main impediment to growth of SMEs in South Africa, as studies by Neneh and Smit (2012) established that SMEs that received debt financing are neither competitive nor innovative and do not create more jobs than SMEs that do not have access to debt finance. So it is imperative for policy to first focus on nurturing the key components of high growth SMEs in all existing and potential entrepreneurs, alongside providing the necessary financial resources needed by these businesses. Policy makers and the South Africa government should adopted a Financial Facilitator Programme (FFP), currently implemented by Singapore, where SMEs can use the program to diagnose their financial health, receive advice on financing options and guidance on loan applications on each stage of the business lifecycle.

5. Lastly, given that South Africa is very unattractive in doing business, the regulatory, administrative and operating environment must be constantly monitored to uncover and remove constraints on small business growth.

\section{REFERENCES}

Accelerated and Shared Growth Initiative -South Africa (2009). [Online] Available:

http://www.fsworks.gov.za/policies/broad_policies/asgisa.pdf [Accessed 27 October, 2012]

Andzelic G, Dzakovic V, Lalic B, Zrnic D, Palcic I (2011). Evaluating the impact of environmental factors on the international competitiveness of Small and Medium sized Enterprises in the Western Balkans. Afr. J. Bus. Manage. 5(4):1253-1265.

Autio E (2005). GEM 2005 Report on High-Expectation Entrepreneurship. Global Entrepreneurship Monitor: London.

Autio E, Arenius P, Wallenius H (2000). Economic Impact of Gazelles in firms in Finland, Working Paper 2000/3.

Biljon G (2012). R400 million venture fund launched to benefit high impact entrepreneurs. Business Partners Limited. Available at: http://www.businesspartners.co.za/forum/topics/r400-million-venturefund-launched-to-benefit-high-impact-entrepr. Accessed 24 October, 2012.

Branscomb ML, Auerswald EP (2002). Between Invention and Innovation An Analysis of Funding for Early-Stage Technology Development. Online, Available at: http://www.atp.nist.gov/eao/gcr02841/gcr02-841.pdf. Accessed 8 July 2012.

Bruderl J, Preisendorfer P (2000). Fast Growing Businesses. Empirical Evidence from a German Study. Int. J. Sociol. 30(1):45-70.

Chodokufa K (2009). An analysis of the business relationship between SMEs and insurance companies in the Nelson Mandela metropolitan area. Masters Dissertation, Faculty of Management and Commerce, University of Fort Hare, South Africa.

CIB Insurance Administrators (CIB) (2012). Support crucial to assist SME sector with SA's growth plans. Online, Available at: http://www.fanews.co.za/article.asp?ShortTerm_Insurance 15,Gener al 1217,Support_crucial to_assist_SME_sector_with_SAs_growth_p lans_ 12748.Accesses $5^{\text {th }}$ October, 2012.

Clover TA, Darroch MAG (2005) .Owner's perception of factors that constrain the survival and growth of small, medium and micro agribusinesses in KwaZulu-Natal, South Africa. Agrekon 44(2):238263.

Dobni CB, Luffman G (2003). Determining the scope and impact of market orientation profiles on strategy implementation and performance. Strategic Manage. J., 24(6): 577-585.

Department for Business Enterprise \& Regulatory Reform (BERR) (2008). High Growth Firms in the United Kingdom: Lessons from an 
analysis of Comparative UK Performance, $\| B E R R$ Economics Paper No. 3, November.

Department of Government communication and Information System (2012). Towards the 2012 State of the Nation (SoNA) address. Working Together We Can Do More. Online, retrieved from: http://www.gcis.gov.za/content/resourcecentre/newslettersmagazines/buabriefs/2012/8Feb2012. Accessed 24 October, 2012.

EIM (2006). Entrepreneurship in the Netherlands. High-growth enterprises; running fast but still keeping control, EIM Business and Policy Research.

Fatoki O, Garwe D (2010). Obstacles to the growth of new SMEs in South Africa: A principal component analysis approach. Afr. J. Bus. Manage. 4(5): 729-738.

Fatoki O, Odeyemi A (2010). Which New Small and Medium Enterprises in South Africa Have Access to Bank Credit? Int. J Bus. Manage. 5(10):1-9.

Fatoki OO (2011). The Impact of Human, Social and Financial Capital on the Performance of Small and Medium-Sized Enterprises (SMEs) in South Africa, J. Soc. Sci. 29(3):193-204.

Fatoki OO (2012). The Impact of Ethics on the Availability of Trade Credit to New Small and Medium Sized Enterprises (SMEs) in South Africa, J. Soc. Sci. 30(1):21-29.

Ferrell OC, Gonzalez-Padron TL, Hult GTM (2010). From Market Orientation to Stakeholder. J. Public Policy \& Marketing, 29 (1) 93-9.

FinMark (2010). FinScope South Africa Small Business Survey 2010. FinMark Trust. Online, available at http://www.finmarktrust.org.za/ pages/Focus-Areas/Small,-Micro-and-Medium-

Enterprises.aspx?randomID=b2697f82-2112-499cbde521944c67abae\&linkPath=8\&IID=8_11. Accessed 21 May 2012.

FinMark Trust (2006). FinScope Small Business Survey Report. Online, Available at http://www.finmarktrust.org.za. Accessed 15 September 2010.

Fischer E, Reuber AR (2003). "Support for Rapid-Growth Firms: A Comparison of the Views of Founders, Government Policymakers, and Private Sector Resource Providers". J. Small Bus. Manage. 41:346-365.

Friar J, Meyer M (2003). Entrepreneurship and Start-ups in the Boston Region: Factors Differentiating High-growth Ventures from Microventures. Small Bus. Econ, 21:145-152.

Fritsch $M$ (2011). The effect of new business formation on regional development - Empirical evidence, interpretation, and avenues for further research, Jena Economic Research Papers \# 2011-006.

Fritsch M, Mueller P (2004). Effects of Business Formation on Regional development over time. Regional Stud. 38:961-975.

Fritsch M, Weyh A (2006). How Large are the Direct Employment Effects of New Business? An Empirical Investigation for West Germany, Small Business Economics, 27:245-260.

Government Gazette of the Republic of South Africa (2003). National Small Business Amendment Act [On-line] Available: http//www.info.gov.za/gazette/acts/2003/a26-03/pdf [Accessed 2 December 2009].

Ganotakis P (2010). Founder's human capital and the performance of UK new technology based firms. Small Bus. Econ. 35(4):1-21.

Hult T, Ketchen D (2001).Does market orientation matter? A test of the relationship between positional advantage and performance. Strategic Manage. J., 22:899-906.

Kirca A, Jayachandran S, Bearden W (2005). Market orientation: a meta-analytic review and assessment of its antecedents and impact on performance. J. Market. 69(2):24-41.

Kleynhans E (2006). The Role of Human Capital In The Competitive Platform Of South African Industries. SA J. Human Resource Manage, 4 (3), 55-62

Kongolo M (2010). Job creation versus job shedding and the role of SMEs in economic development. Afr. J. Bus. Manage. 4(11):22882295.

Krause W (2011). Open Innovation: A Top Priority For SMEs. IQ business. Online, Available at: http://www.iqgroup.com/africa/news/entry/open_innovation_a_top_pri oroty_for_smes/. Accessed 24 October, 2012.

Krause W, Schutte C, du Preez N (2012). Open innovation in South African small and medium-sized enterprises. CIE42 Proceedings, 1618 July 2012, Cape Town, South Africa.
Krotowski M (2012). The Relationship between Innovation and Economic Growth. Online, Available at: http://wp.tt.psu.edu/ mattkrotowski/2012/04/28/the-relationship-between-innovation-andeconomic-growth/. Accessed 7 July, 2012.

Labuschagne JR (2010). Human capital constraints in South Africa: A firm level analysis. Masters Dissertation, North West University, South Africa.

Lee SJ, Hsieh CJ (2010). Research in Relating Entrepreneurship, Marketing Capability, Innovative Capability and Sustained Competitive Advantage. Proceedings of the 2010 EABR (Business) Conference and 2010 ETLC (Education) Conference, Dublin, Ireland, 7-10 June 2010.

López-García P, Puente S (2009). What makes a high-growth firm? A probit analysis using Spanish firm-level data. Banco de EspañaDocumentos de Trabajo 0920.

Maas G, Herrington M (2008). Global Entrepreneurship Monitor (GEM): South African report. Graduate School of Business. Cape Town: University of Cape Town.

Mahembe E (2011). Literature review on small and medium enterprises' access to credit and support in South Africa.National Credit Regulator (NCR).

Mason C (2011). Creating Good Public Policy to Support High Growth Firms. EPRC Seminar, Glasgow Scotland: 16 February 2011.

Mirela B (2008). Innovation - The Characteristic Tool Of Entrepreneurs. Online, Available at: http://steconomice.uoradea.ro/anale/ volume/2008/v4-management-marketing/1000.pdf. [Accessed 4th January, 2011].

Mitusch K, Schimke A (2011). Gazelles-High-Growth Companies. Consortium Europe INNOVA Sectoral Innovation Watch. Online, Available

http://ec.europa.eu/enterprise/policies/innovation/files/proinno/gazelle s-final-report en.pdf. Accessed 26 October, 2012.

Morgan NA, Vorhies DW, Mason CH (2009). Market Orientation, Marketing Capabilities, and Firm Performance. Strat. Mgmt. J., 30: 909-920.

Morris MH, Zahra S (2000). Adaptation of the business concept over time: The case of historically disadvantaged South African owner/ managers. J. Small Bus manage, 38(1): 92-100.

Neneh BN (2011). The impact of entrepreneurial characteristics and business practices on the long term survival of small and medium enterprises (SMEs). Master thesis submitted at the University of the Free State, Bloemfontein, South Africa.

Neneh BN, Smit AVA (2012).Exploring the effectiveness of debt financing for new SMEs in fostering economic development: Regional evidence from South Africa. A paper presented at the $5^{\text {th }}$ International Business Conference, 27- 31 August, 2012, Mombassa, Kenya.

Nenzhelele T (2009). Factors influencing the productivity of small and medium enterprises (SMEs) in South Africa. A dissertation submitted in fulfillment of the requirements for the degree Magister Technologiae: Engineering: Industrial in the Department of Industrial Engineering Faculty of engineering and the built environment Tshwane University of Technology

O'Sullivan D, Dooley L (2008). Defining Innovation. Sage Publications.

Organisation for Economic Co-operation and Development (OECD) (2001). The Well- Being of Nations: The Role of Human and Social Capital. Paris: OECD.

Organisation for economic co-operation and development (OECD) 2002. High-Growth SMEs and Employment. Online, Available at: http://www.oecd.org/industry/smesandentrepreneurship/2493092.pdf. Accessed 26 October, 2012.

Rogerson CM (2008). Tracking SMME development in South Africa: Issues of finance, training and regulatory environment. Urban Forum, 19: $61-81$.

Schreyer P (2000). "High-Growth Firms and Employment." OECD Science, Technology and Industry Working Papers, 2000/3. Paris: OECD Publishing.

Solow R (1997). Learning from "Learning by Doing". Stanford, California: Stanford University Press.

Stam E, Schutjens V (2005). "The fragile success of team start-ups", Max Planck Institute Discussion Paper \#17-2005. Jena, Germany: Max Planck Institute of Economics. 
Stam E, Schutjens V, Meijaard J (2006). Young Firm Exit: Types and explanations. Mimeo, EIM: Zoetermeer.

Statistics South Africa (2012). Quarterly Labour Force Survey: Quarter 3 (July to September), 2012. Press Statement. Available at: http://www.statssa.gov.za/news_archive/press_statements/QLFS-Q32012.pdf. Accessed 16 November, 2012.

Toomey DC (1998). South African Small Business Growth through Inter-firm Linkages. PhD dissertation, Rhodes University.

Utterback JM (1996). Mastering the Dynamics of Innovation. Harvard, Harvard Business School Press.

Verheul I, van Mil L (2008). What Determines the Growth Ambition of Dutch Early-Stage Entrepreneurs? Online, Available at: http://www.entrepreneurship-sme.eu/pdf-ez/H200811.pdf.Accessed 2 July 2012.

Vincent HL, Bharadwaj, GS, Challagalla NG (2004). Does Innovation Mediate Firm Performance? : A Meta-Analysis of Determinants and Consequences of Organisational Innovation [online]. Available at: http://smartech.gatech.edu/handle/1853/10731. [ Accessed 2nd September 2010].
Vivarelli M (2004). Are all the Potential Entrepreneurs So Good?, Small Bus. Economics, 23(1): 41-49.

Wells S, Hungerford G (2011). "High Growth Entrepreneurship: The Key to Canada's Future Economic Success", Policy Options, September 2011; Centre for High Impact Entrepreneurship and GEM, 2011 HighImpact Entrepreneurship Global Report.

Wiklund J, Shepherd D (2003). Aspiring for, and achieving growth. The moderating role of resources and opportunities. J. Manage Studies, 40 (8): 1919- 1941.

Willemse J (2010). The Forum SA. SME Failure Statistics. Online available: http://www.theforumsa.co.za/forums/showthread.php? $\mathrm{t}=7808$. Accessed 21 September, 2010. 